\title{
KLASIFIKASI PENENTUAN PENERIMA BANTUAN PANGAN NON TUNAI MENGGUNAKAN METODE K-MEANS CLUSTERING
}

\author{
Sulton Ghousi Pratama ${ }^{1}$, Ali Mahmudi ${ }^{2}$, Sentot Achmadi ${ }^{3}$ \\ Program Studi Teknik Informatika S1, Fakultas Teknologi Industri \\ Institut Teknologi Nasional Malang, Jalan Raya Karanglo km 2 Malang, Indonesia \\ Sultonpratama9599@gmail.com
}

\begin{abstract}
ABSTRAK
Proses penentuan penerima Bantuan Pangan Non Tunai (BPNT) di Pemerintah Desa Rembun belum sepenuhnya memanfaatkan teknologi dalam menentukan penerima bantuan. Proses penentuan penerima BPNT saat ini masih dilakukan secara manual. Sehingga membutuhkan waktu yang lama dan memiliki kemungkinan terjadi kesalahan saat menentukan penerima BPNT.

Sistem yang dibuat menerapkan metode K-Means Clustering untuk proses penentuan penerima BPNT. Sehingga dapat membantu memudahkan petugas dalam menentukan penerima BPNT dan dapat mempersingkat waktu dalam pengolahan data. Kriteria yang digunakan pada sistem ini terdapat 9 kriteria yaitu pekerjaan, jenis atap rumah, jenis dinding rumah, jenis lantai rumah, sumber penerangan utama, sumber air minum, bahan bakar memasak tempat mck, dan status kepemilikan rumah. Sistem ini dirancang menggunakan Visual Basic 2008 dengan Microsoft SQL Server Sebagai databasenya.

Hasil pengujian menunjukkan bahwa beberapa fungsi yang terdapat dalam sistem dapat berjalan dengan baik. Penelitian ini menunjukkan bahwa sistem penentuan penerima bantuan pangan non tunai menggunakan metode Clustering K-Means menghasilkan data yang layak mendapatkan bantuan sesuai kriteria yang telah ditentukan.. Sehingga, sistem ini diharapkan dapat membantu dalam menentukan penerima bantuan pangan non tunai secara cepat dan akurat.
\end{abstract}

Kata kunci : Pemerintah Desa Rembun, Bantuan Pangan Non Tunai, K Means Clustering, Visual Basic 2008.

\section{PENDAHULUAN}

\subsection{Latar Belakang}

Rembun adalah sebuah desa di wilayah

Kecamatan Dampit, Kabupaten Malang, Provinsi Jawa Timur. Pemerintah Desa Rembun menjalankan segala macam program pemerintah dalam mengatasi kemiskinan pada warga, khususnya warga Desa Rembun. Salah satunya program pemerintah adalah program Bantuan Pangan Non Tunai atau yang biasa disebut BPNT. BPNT merupakan bantuan sosial pangan dalam bentuk non tunai dari pemerintah yang diberikan kepada Keluarga Penerima Manfaat (KPM) setiap bulannya. BPNT menjadi program yang lebih efektif dalam mengatasi permasalahan ini, diikarenakan banyak warga yang kurang mampu masih sulit untuk memenuhi kebutuhan seharihari.

Proses penggalian data dalam menentukan penerima BPNT, saat ini masih dilakukan secara manual dengan cara dituliskan dalam buku arsip, yang cukup memakan waktu dalam penulisan juga menjadi kendala dalam penentuan setiap warga yang mendapatkan BPNT. Selain itu, penumpukan data warga yang kurang mampu dikarenakan tidak tahu layak atau tidaknya mendapatkan bantuan juga menjadi kendala lainnya. Jika sudah mengetahui mana yang layak mendapatkan bantuan maupun yang tidak, maka tidak perlu bingung untuk memilih warga yang mendapatkan bantuan.

Perkembangan teknologi computer yang semakin canggih, sangat memungkinkan untuk membuat suatu sistem yang dapat menyelesaikan permasalahan di atas (khususnya pada penentuan penerima BPNT). Dari permasalahan tersebut, timbullah suatu ide yaitu sebuah sistem yang menggunakan metode K-Means Clustering untuk membantu petugas dalam menentukan penerima BPNT. Sistem ini dibuat menggunakan Software Visual Basic 2008 sebagai aplikasinya dan Ms. SQL Server sebagai databasenya. Agar lebih tepat, akurat dan mempermudah Pemerintah Desa Rembun dalam menentukan warga yang layak mendapatkan bantuan maupun tidak.

\subsection{Rumusan Masalah}

Berdasarkan latar belakang yang telah dikemukakan sebelumnya, rumusan masalah pada sistem ini adalah sebagai berikut:

1. Bagaimana membangun sistem untuk menentukan warga yang mendapatkan bantuan pangan non tunai?

2. Bagaimana menerapkan metode K-Means Clustering dalam menentukan penerina bantuan pangan non tunai berbasis Dekstop dengan VB.Net pada Visual Basic 2008? 


\subsection{Tujuan} adalah :

Adapun tujuan dari pengembangan sistem ini

1. Membangun sistem untuk menentukan warga yang mendapatkan bantuan pangan non tunai.

2. Menerapkan metode K-Means Clustering dalam menentukan penerina bantuan pangan non tunai berbasis Dekstop dengan VB.Net pada Visual Basic 2008.

\subsection{Batasan Masalah}

Berdasarkan pembuatan aplikasi ini, maka akan diterapkan beberapa batasan masalah. Batasan batasan masalah tersebut antara lain :

1. Sumber data yang digunakan dalam pengembangan sistem ini merupakan data keluarga di Pemerintah Desa Rembun pada tahun 2015 sebanyak 106 data.

2. Kriteria yang digunakan pada penelitian ini diantaranya adalah pekerjaan, jenis atap rumah, jenis dinding rumah, jenis lantai rumah, sumber penerangan utama, sumber air minum, bahan bakar memasak, tempat mck, dan status kepemilikan rumah.

3. Metode yang digunakan adalah metode KMeans Clustering. Nilai $\mathrm{K}$ yang di gunakan adalah sangat layak, layak, tidak layak, dan sangat tidak layak.

4. Hakses pengguna dalam sistem ini adalah Administrator dan Operator Desa pada Pemerintah Desa Rembun.

5. Bahasa pemograman dalam pengembangan sistem ini menggunakan Visual Basic.Net pada Visual Studio 2008 dengan database Ms. SQL Server 2014.

\section{TINJAUAN PUSTAKA \\ 2.1 Penilitian Terdahulu}

Metode $\mathrm{K}$ - Means Clustering sering dipakai untuk menyelesaikan masalah secara studi kasus. Salah satunya Fitri Yunita, dalam penelitiannya yang Menggunakan Algoritma Kmeans Clustering Pada Penerimaan Mahasiswa Baru Pada Universitas Islam Indragiri Tahun 2018. K-Means membentuk menjadi 3 cluster mahasiswa, dengan cluster pertama 195 items, cluster kedua 271 items dan cluster ketiga sejumlah 50 items. Hasil penelitian ini digunakan sebagai salah satu dasar pengambilan keputusan untuk menentukan strategi mempromosikan masing-masing program studi yang ada di universitas islam indragiri. [1]

\subsection{Dasar Teori}

\subsubsection{Data Mining}

Data mining merupakan salah satu solusi untuk menjelaskan proses penggalian informasi dalam suatu basis data yang berskala besar dan proses klasifikasi otomatisasi kasus berdasarkan pola data yang diperoleh dari data set. Data mining dapat diterapkan pada berbagai bidang, dibagi menjadi empat kelompok : model prediksi), analisis cluster, analisis aosiasi, dan deteksi anomaly [2].

\subsection{2. $\mathrm{K}$ - Means Clustering}

K-Means clustering merupakan salah satu metode yang mengelompokan data ke dalam satu atau lebih kelompok/cluster. Dalam satu kelompok/cluster memiliki anggota berupa datadata yang memiliki karakteristik yang sama dan data yang memiliki karakteristik yang berbeda dikelompokan dengan kelompok/cluster yang lain sehingga dalam satu kelompok/cluster

memiliki data yang tingkat variasinya kecil [3]

Langkah-langkah melakukan clustering dengan metode K Means adalah sebagai berikut:

1. Pilih jumlah cluster $\mathrm{k}$.

2. Inisialisasi $\mathrm{k}$ pusat cluster yang biasanya diberi nilai awal dengan angka-angka random.

3. Alokasikan semua data/ objek ke cluster terdekat dengan menghitung jarak antara data dengan pusat cluster menggunakan teori jarak Euclidean dengan rumus sebagai berikut:

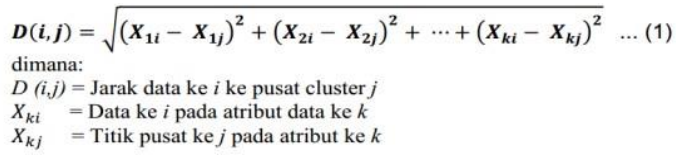

4. Hitung kembali pusat cluster dengan menghitung rata-rata dari semua data/ objek dalam tiap cluster. Jika dikehendaki bisa juga menggunakan median dari cluster tersebut. Jadi rata-rata (mean) bukan satu-satunya ukuran yang bisa dipakai.

5. Hitung kembali jarak setiap data dengan pusat cluster yang baru seperti langkah no c sampai anggota cluster tidak berubah lagi.

\subsubsection{Bantuan Pangan Non Tunai}

Bantuan Pangan Non Tunai merupakan bantuan sosial pangan dalam bentuk non tunai dari pemerintah yang diberikan kepada Keluarga Penerima Manfaat (KPM) setiap bulannya.Tujuan adanya program ini yaitu mengurangi beban pengeluaran KPM dan kendali kepada KPM dalam memenuhi kebutuhan pangan dan mendorong pencapaian tujuan pembangunan berkelanjutan[4]. 


\subsubsection{Visual Basic}

Visual Basic diturunkan dari bahasa BASIC. Visual Basic merupakan bahasa pemrograman yang mudah digunakan terutama untuk membuat aplikasi yang digunakan di sistem operasi windows[5].

\subsubsection{Microsoft SQL Server}

Ms. $S Q L$ adalah sebuah trobosan baru dari Microsoft dalam bidang database untuk pengolahan dan penyimpanan data

\section{ANALISA DAN PERANCANGAN}

Analisis dan perancangan sistem pada klasifikasi penentuan penerima bantuan pangan non tunai menggunakan metode $\mathrm{k}$-means clustering. Selanjutnya akan di jelaskan pada proses analisis dan perancangan sistem.

\subsection{Flowchart}

Pada Gambar 1 Flowchart program menjelaskan tentang alur dari metode K-Means Clustering, di mana metode ini harus menentukan banyaknya cluster dulu, setelah jumlah cluster di tentukan maka akan di lanjutkan dengan

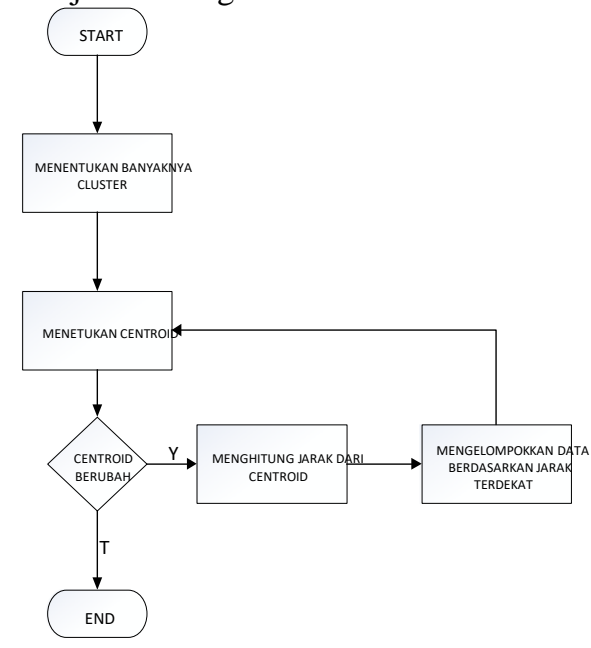

Gambar 1 Flowchart Program

menentukan titik tengahnya, setelah menemukan titik tengahnya maka proses KMeans Clustering selesai, jika titik tengahnya berubah maka proses akan di lanjutkan dengan cara mencari jarak terdekat dan mengelompokkan data berdasarkan jarak terdekat, apabila jarak terdekatnya sudah ditemukan maka proses KMeans clustering selesai.

\subsection{Flowchart Sistem}

Flowchart Sistem diperlihatkan pada gambar 2, dari gambar tersebut menjelaskan tentang sistem yang dijalankan terdapat 2 hak akses. Hak akses yang pertama yaitu operator, yang kedua untuk admin.

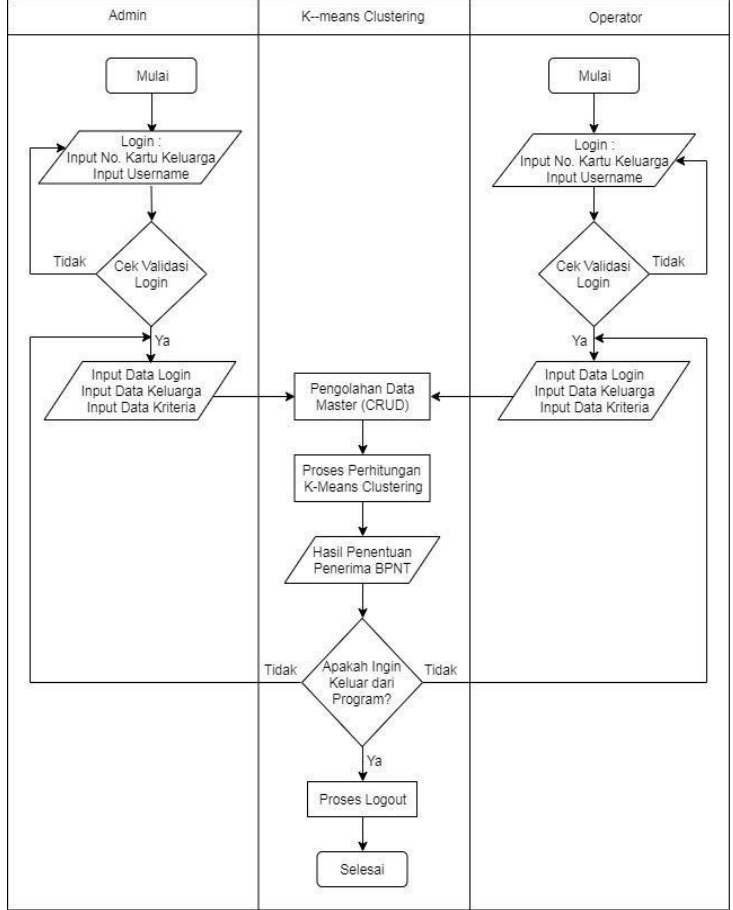

Gambar 2 Flowchart Sistem

Flowchart sistem merupakan suatu cara untuk menggambarkan algoritma dari sistem tersebut. Flowchart dari klasifikasi penentuan penerima bantuan pangan non tunai ini dapat dilihat pada gambar 2 .

Flowchart Sistem diperlihatkan pada gambar 2, dari gambar tersebut menjelaskan tentang sistem yang dijalankan terdapat 2 hak akses. Hak akses yang pertama yaitu operator, yang kedua untuk admin. Dalam sistem ini menggunakan metode k-means clustering sebagai metodenya. Prosedur kedua hak akses dalam menjalankan aplikasi berbeda, untuk admin dalam menjalankan semua menu yang terdapat pada sistem. Sedangkan, untuk operator hanya dapat melakukan login, memasukkan data kriteria, data keluarga, dan melakukan logout.

\subsection{Struktur Menu}

Struktur menu dirancang untuk menyederhanakan suatu sistem yang telah dibangun untuk melihat semua arsitektur sistem yang telah dirancang, tampilan struktur menu yang telah dirancang dapat dilihat pada Gambar 3

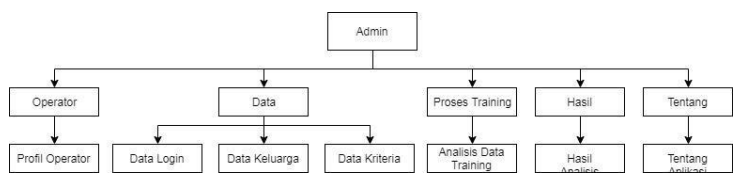

Gambar 3 struktur Menu Administrator.

Struktur Menu Admin diperlihatkan pada gambar 3, dari gambar tersebut menjelaskan tentang pada halaman utama admin terdapat tempat menu 
utama, keempat menu utama tersebut adalah Admin, Data, Proses Metode KMeans Clustering, Hasil, dan Tentang. Pada menu admin dapat mengetahui data profil admin. Menu data dapat melakukan pengolahan data login, data keluarga, dan data kriteria. Selanjutnya pada menu proses metode kmeans clustering yaitu proses untuk menganalisa metode dari data kriteria yang sudah dimasukkan. Menu selanjutnya dari sistem ini adalah menu hasil, yaitu hasil dari analisis metode yang diterapkan.

Untuk struktur menu operator bisa dilihat pada Gambar 4.

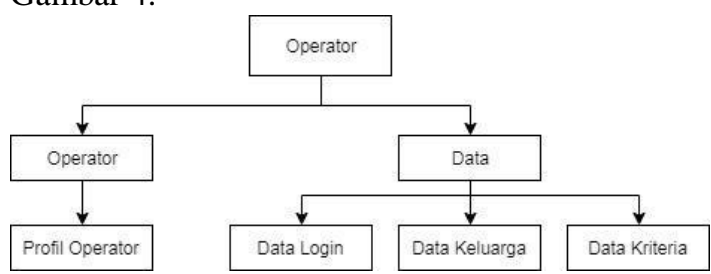

Gambar 4. Struktur Menu Operator.

3.5 Memberikan bobot pada setiap kriteria Memberikan bobot pada setiap kriteria memiliki tujuan yaitu agar semua data menjadi angka sehingga dapat dilakukan perhitungan dengan mudah. Adapun Tabel data training dan Tabel data kriteria yang sudah diberikan bobot masing-masing seperti tabel 1 dan tabel 2.

\begin{tabular}{|c|c|c|c|c|c|}
\hline No & 3507 & 3507 & 3507 & 3507 & 3507 \\
\hline Kartu & 0520 & 0520 & 0520 & 0520 & 0520 \\
\hline Kelu & 1000 & 1000 & 1000 & 1000 & 1000 \\
\hline \multirow[t]{3}{*}{ Arga } & 2009 & 2009 & 2009 & 2009 & 2009 \\
\hline & 0002 & 0003 & 0004 & 0005 & 0006 \\
\hline & 002 & 003 & 004 & 005 & 006 \\
\hline $\mathrm{K} 1$ & $\begin{array}{l}\text { Pedag } \\
\text { ang }\end{array}$ & $\begin{array}{l}\text { Pega } \\
\text { wai } \\
\text { Swast } \\
\text { a }\end{array}$ & Petani & $\begin{array}{l}\text { Peker } \\
\text { ja } \\
\text { Lepas }\end{array}$ & Petani \\
\hline $\mathrm{K} 2$ & $\begin{array}{l}\text { Gent } \\
\text { eng }\end{array}$ & $\begin{array}{l}\text { Gente } \\
\text { ng }\end{array}$ & $\begin{array}{l}\text { Gente } \\
\text { ng }\end{array}$ & $\begin{array}{l}\text { Gente } \\
\text { ng }\end{array}$ & $\begin{array}{l}\text { Gente } \\
\text { ng }\end{array}$ \\
\hline K3 & $\begin{array}{l}\text { Temb } \\
\text { ok }\end{array}$ & $\begin{array}{l}\text { Temb } \\
\text { ok }\end{array}$ & $\begin{array}{l}\text { Temb } \\
\text { ok }\end{array}$ & $\begin{array}{l}\text { Temb } \\
\text { ok }\end{array}$ & $\begin{array}{l}\text { Temb } \\
\text { ok }\end{array}$ \\
\hline $\mathrm{K} 4$ & Ubin & Ubin & Ubin & Ubin & Ubin \\
\hline $\mathrm{K} 5$ & $\begin{array}{l}\text { Listri } \\
\mathrm{k}\end{array}$ & $\begin{array}{l}\text { Listri } \\
\mathrm{k}\end{array}$ & $\begin{array}{l}\text { Listri } \\
\mathrm{k}\end{array}$ & $\begin{array}{l}\text { Listri } \\
\mathrm{k}\end{array}$ & $\begin{array}{l}\text { Listri } \\
\mathrm{k}\end{array}$ \\
\hline K6 & $\begin{array}{l}\text { Kem } \\
\text { asan }\end{array}$ & $\begin{array}{l}\text { Sum } \\
\text { ur }\end{array}$ & $\begin{array}{l}\text { Sum } \\
\text { ur }\end{array}$ & $\begin{array}{l}\text { Sum } \\
\text { ur }\end{array}$ & $\begin{array}{l}\text { Kem } \\
\text { asan }\end{array}$ \\
\hline K7 & Gas & Gas & Gas & Gas & Gas \\
\hline K8 & $\begin{array}{l}\text { Jamb } \\
\text { an } \\
\text { Sendi } \\
\text { ri }\end{array}$ & $\begin{array}{l}\text { Jamb } \\
\text { an } \\
\text { Sendi } \\
\text { ri }\end{array}$ & $\begin{array}{l}\text { Jamb } \\
\text { an } \\
\text { Sendi } \\
\text { ri }\end{array}$ & $\begin{array}{l}\text { Jamb } \\
\text { an } \\
\text { Sendi } \\
\text { ri }\end{array}$ & $\begin{array}{l}\text { Jamb } \\
\text { an } \\
\text { Sendi } \\
\text { ri }\end{array}$ \\
\hline K9 & $\begin{array}{l}\text { Milik } \\
\text { sendi } \\
\text { ri }\end{array}$ & $\begin{array}{l}\text { Milik } \\
\text { sendi } \\
\text { ri }\end{array}$ & $\begin{array}{l}\text { Milik } \\
\text { sendi } \\
\text { ri }\end{array}$ & $\begin{array}{l}\text { Milik } \\
\text { sendi } \\
\text { ri }\end{array}$ & $\begin{array}{l}\text { Milik } \\
\text { sendi } \\
\text { ri }\end{array}$ \\
\hline
\end{tabular}

Tabel 2. Bobot pada setiap kriteria

\begin{tabular}{|c|c|c|c|}
\hline No & Kriteria & No & Kriteria \\
\hline \multirow[t]{2}{*}{1.} & \multirow{2}{*}{ 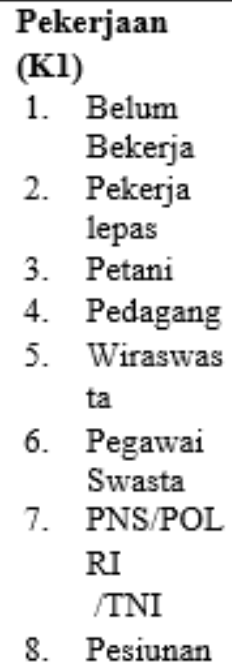 } & 2. & \begin{tabular}{ll}
\multicolumn{3}{l}{ Jenis Atap } \\
Rumah (K2) \\
0. Lainnya \\
1. Daun \\
2. Seng \\
3. & Genteng
\end{tabular} \\
\hline & & 3. & $\begin{array}{ll}\text { Jenis Dinding } \\
\text { Rumah (K3) } \\
\text { 0. Lainnya } \\
\text { 1. Bambu } \\
\text { 2. Kayu } \\
\text { 3. } & \text { Tembok }\end{array}$ \\
\hline 4. & $\begin{array}{l}\text { Jenis Lantai } \\
\text { Rumah (K4) } \\
\text { 0. Lainnya } \\
\text { 1. Tanah } \\
\text { 2. Semen } \\
\text { 3. Ubin }\end{array}$ & 5. & $\begin{array}{l}\text { Sumber } \\
\text { Penenerangan } \\
\text { Utama (K5) } \\
\text { 0. Lainnya } \\
\text { 1. Minyak } \\
\text { 2. Listrik } \\
\text { 3. Jenset }\end{array}$ \\
\hline
\end{tabular}

\subsection{Menentukan Jumlah Cluster dan Centroid Awal}

Data bobot dari kriteria-kriteria data keluarga tersebut akan dilakukan perhitungan. Tahap awal perhitungan data menggunakan metode K-Means adalah dengan menentukan jumlah k cluster yang akan dibentuk. Pada contoh perhitungan awal ini akan dilakukan perhitungan dengan nilak $\mathrm{k}$ sebanyak 4, kemudian diperlukan penentuan centroid awal terlebih dahulu. Tabel 3 adalah centroid awal.

Tabel 3. Centroid Awal Cen

\begin{tabular}{cccccccccc}
\hline & $\mathrm{K} 1$ & $\mathrm{~K}$ & $\mathrm{~K}$ & $\mathrm{~K}$ & $\mathrm{~K}$ & $\mathrm{~K}$ & $\mathrm{~K}$ & $\mathrm{~K}$ & $\mathrm{~K} 9$ \\
& & 2 & 3 & 4 & 5 & 6 & 7 & 8 & \\
\hline \multirow{2}{*}{ troid } & & 3 & 3 & 2 & 2 & 2 & 1 & 1 & \\
$\mathrm{C} 1$ & 1 & & & & & & & & 2 \\
$\mathrm{C} 2$ & 2 & 3 & 32 & 23 & 1 & 3 & 3 \\
$\mathrm{C} 3$ & 3 & 3 & 33 & 23 & 3 & 3 & 3 \\
& & & & & & & & & \\
$\mathrm{C} 4$ & 8 & 3 & 33 & 22 & 3 & 3 & 3 \\
& & & & & & & & & \\
\end{tabular}




\section{HASIL DAN PEMBAHASAN}

\subsection{Tampilan Sistem}

\section{Halaman Splash Screen}

Halaman splash screen merupakan tampilan paling awal ketika sistem dijalankan Halaman splash screen yang dirancang ditampilkan pada gambar 5 .

\section{Aplikasi}

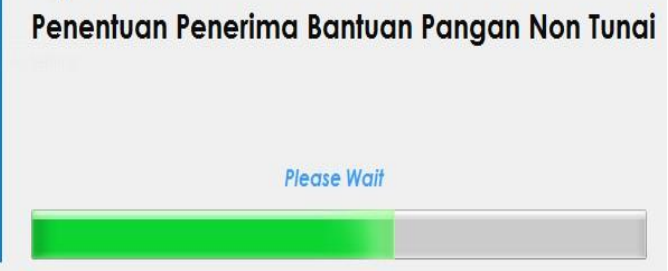

Gambar 5. Halaman Splash Screen.

\section{Form Login}

Halaman login merupakan halaman untuk masuk pada sistem. User harus memasukkan no kartu keluarga dan username yang telah terdaftar pada sistem. Halaman login ditampilkan pada gambar 6.

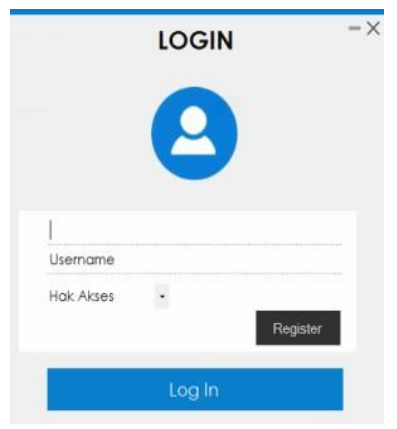

Gambar 6. Form Login

\section{Form Register}

Halaman register merupakan halaman untuk memasukkan data register yang digunakan hak akses menjalankan program. User harus masuk terlebuh dahulu dengan mengunakan no kartu keluarga, username, dan hak akses yang telah terdaftar pada sistem. Halaman register ditampilkan pada gambar 7 .

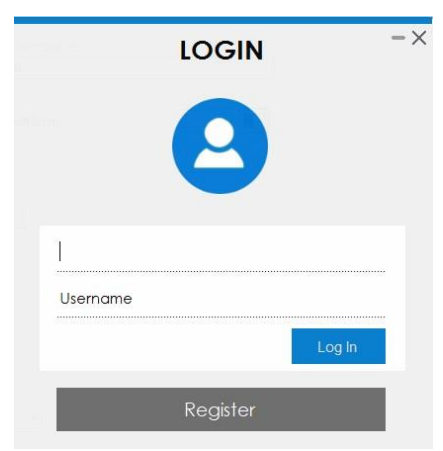

Gambar 7. Form Login

\section{Form Menu Admin}

Halaman administrator merupakan halaman yang akan tampil ketika user masuk kedalam sistem dengan mengunakan hak akses admin. Terdapat beberapa menu yang terdapat pada halaman administrator. halaman administrator ditampilkan pada gambar 8 .

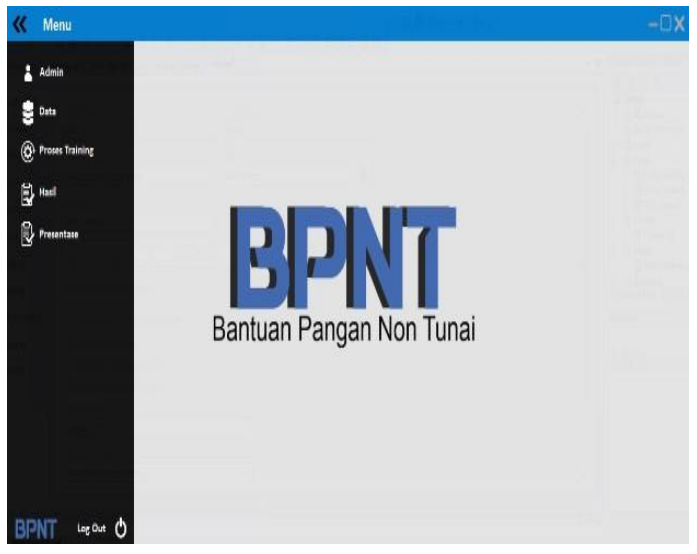

Gambar 8. Form Menu Admin

\section{$5 \quad$ Form Menu Operator}

Halaman operator memiliki fitur menu yang berbeda dengan hak akses yang lain. Halaman operator ini dikhususkan untuk operator yang akan membantu admin dalam memasukkan data keluarga dan data kriteria. Berikut antramuka operator ditampilkan pada gambar 9.

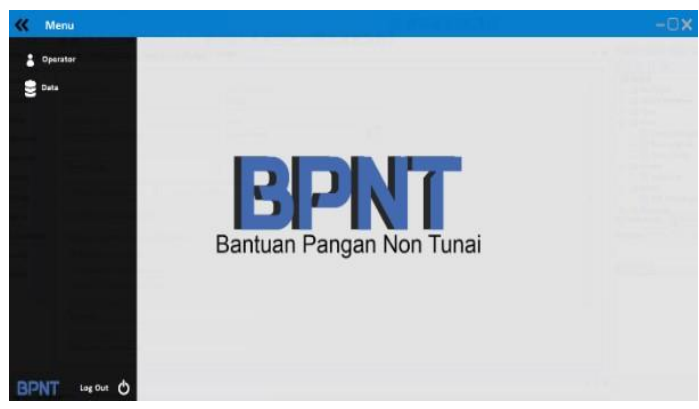

Gambar 9. Form Menu Operator

Halaman data kriteria ini digunakan untuk menginputkan data kriteria. Halaman input data kriteria di tampilkan pada Gambar 10.

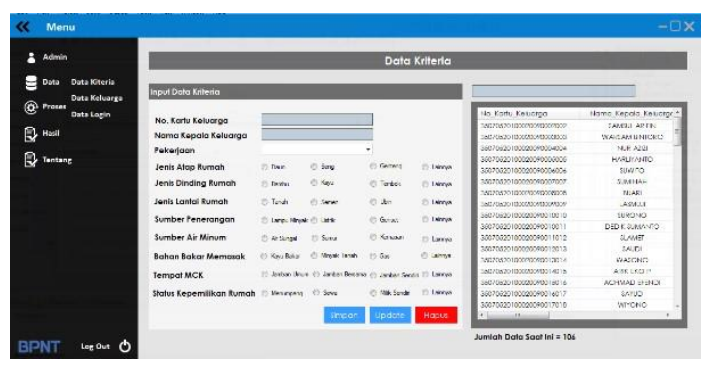

Gambar 10. Form Data Kriteria 
6 Form Data Login

Halaman data login ini digunakan untuk menginputkan data login. Halaman input data di tampilkan pada gambar 11

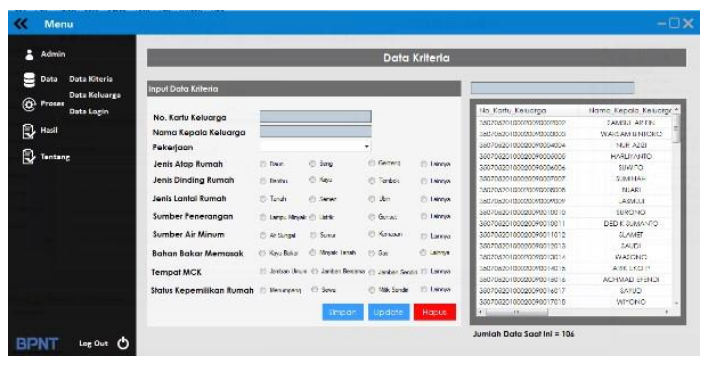

Gambar 11 Form Data Login

7 Form Proses Training

Form menu proses training di gunakan untuk menampilkan hasil dari perhitungan metode $K$ Means Clustering. Halaman menu proses training di tampilkan pada gambar 11. menampilkan hasil dari penentuan penerima bantuan pangan non tunai pada sistem. Halaman menu hasil normalisasi di tampilkan pada gambar 12 .

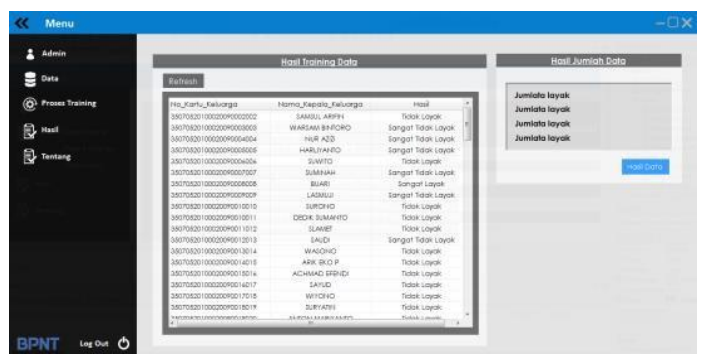

Gambar 12. Hasil Normalisasi

11. Form Tentang

Halaman tentang digunakan untuk menampilkan tentang aplikasi dan saran pada sistem penentuan penerima bantuan pangan non tunai. Halaman tentang ditampilkan pada gambar 13 .

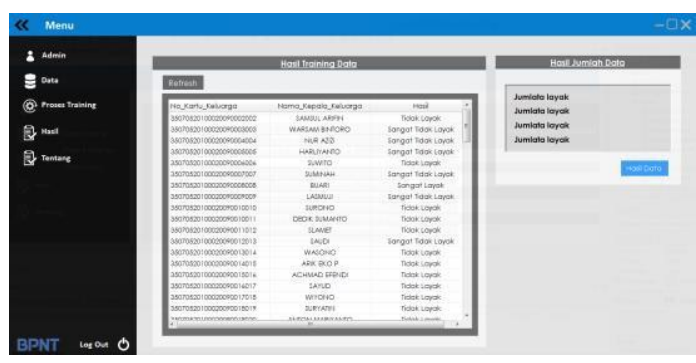

Gambar 13 Form Tentang

\subsection{Pengujian Metode}

Centroid awal sudah ditentukan, kemudian menghitung jarak setiap data ke centroid. Proses ini bertujuan untuk mencari jarak terpendek antara objek ke centroid dengan persamaan perhitungan Euclidean Distance

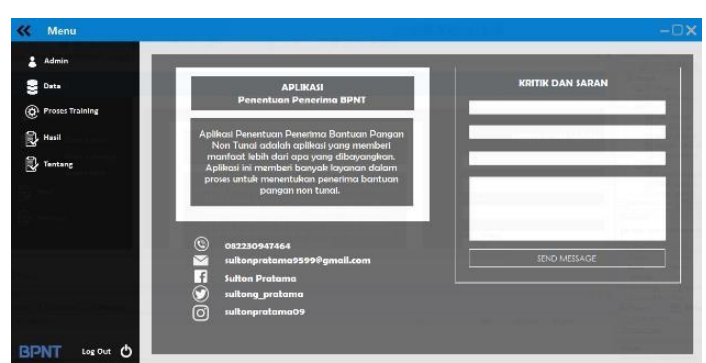

Gambar 14 Form Hasil

1. Perhitungan iterasi 1

$$
\begin{gathered}
d\left(x_{1}, c_{1}\right)=\sqrt{\begin{array}{r}
(4-1)^{2}+(3-3)^{2}+(3-3)^{2}+ \\
(3-2)^{2}+(2-2)^{2}+
\end{array}} \\
\sqrt{\begin{array}{r}
(3-2)^{2}+(3-1)^{2}+(3-1)^{2}+ \\
(3-2)^{2}
\end{array}} \\
\sqrt{20=} 4,47
\end{gathered}
$$

Hasil Perhitungan pada centroid tersebut dilakukan sebanyak data pada tabel data keluarga dengan menggunakan 4 centroid. Hasil perhitungan jarak semua data centroid pada tabel 4 .

$$
\text { Form Hasil }
$$

\section{Tabel 4 Hasil Perhitungan Iterasi 1}

\begin{tabular}{lccccc}
\hline $\begin{array}{l}\text { No Kartu } \\
\text { Keluarga }\end{array}$ & C1 & C2 & C3 & C4 & Cluster \\
\hline 3507052010002 & 4,4 & 3 & 1,4 & 4,1 & 3 \\
0090002002 & 7 & & 1 & 2 & \\
3507052010002 & 5,9 & 4,6 & 3,1 & 2 & 4 \\
0090003003 & 2 & 9 & 6 & & \\
& & & & & \\
3507052010002 & 3,7 & 2,6 & 1 & 5 & 3 \\
0090004004 & 4 & 5 & & & \\
3507052010002 & 3,3 & 2,4 & 1,4 & 6 & 3 \\
0090005005 & 2 & 5 & 1 & & \\
3507052010002 & 3,8 & 2,4 & 0 & 5,1 & 3 \\
0090006006 & 7 & 5 & & &
\end{tabular}

Setelah hasil diperoleh dari iterasi pertama, langkah berikutnya adalah menghitung jumlah rata-rata data sesuai dengan hasil cluster yang sama yang digunakan untuk menentukan nilai centroid terbaru. Berikut perhitungannya.

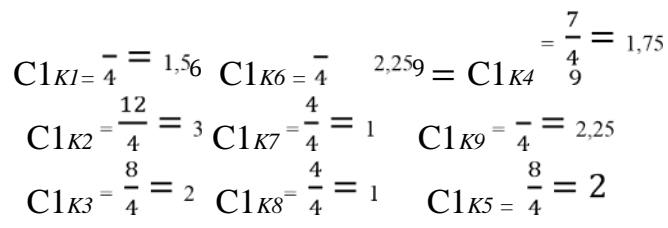

Apabila hasil centroid yang terbaru berubah, maka perlu di lakukan iterasi lagi sampai centroid tidak ada yang berubah daripada centroid sebelumnya. 
Tabel 5. Centroid

\begin{tabular}{ccccc}
\hline $\begin{array}{c}\text { Cen } \\
\text { troid }\end{array}$ & C1 & C2 & C3 & C4 \\
\hline $\mathrm{K} 1$ & 1,5 & 1,5 & 2,85 & 4,8 \\
$\mathrm{~K} 2$ & 3 & 3 & 2,98 & 3 \\
$\mathrm{~K} 3$ & 3 & 3 & 2,95 & 3 \\
$\mathrm{~K} 4$ & 1,75 & 1,5 & 2,65 & 2,6 \\
$\mathrm{~K} 5$ & 2 & 2 & 2 & 2 \\
$\mathrm{~K} 6$ & 2,25 & 3 & 2,72 & 2,6 \\
$\mathrm{~K} 7$ & 1 & 1 & 3 & 3 \\
$\mathrm{~K} 8$ & 1 & 3 & 2,94 & 3 \\
$\mathrm{~K} 9$ & 2,25 & 2 & 2,79 & 2,87 \\
\hline
\end{tabular}

2. Hasil Perhitungan Metode Hasil perhitungan metode adalah hasil dari penentuan penerima bpnt menggunakan metode k-means clustering. Perhitungan dengan 3 kali iterasi menghasilkan data hasil dari penentuan penerima bpnt. Cluster yang bernilai 1 yaitu sangat layak, cluster bernilai 2 yaitu layak, cluster bernilai 3 yaitu tidak layak, dan cluster bernilai 4 yaitu sangat tidak layak. Data hasil terdapat pada tabel 6.

Tabel 6 Hasil Perhitungan Metode C Hasil

\begin{tabular}{llc}
\hline $\begin{array}{l}\text { No Kartu } \\
\text { Keluarga }\end{array}$ & & \\
\hline 35070520100020 & 4 & Sangat Tidak Layak \\
090002002 & & \\
35070520100020 & 4 & Sangat Tidak Layak \\
090003003 & & \\
35070520100020 & 3 & Tidak Layak \\
090004004 & & \\
35070520100020 & 3 & Tidak Layak \\
090005005 & & Tidak Layak \\
35070520100020 & 3 & \\
090006006 & &
\end{tabular}

Tabel 7 Hasil Perbandingan

\begin{tabular}{lcc}
\hline $\begin{array}{l}\text { No Kartu } \\
\text { Keluarga }\end{array}$ & $\begin{array}{c}\text { Data } \\
\text { Lama }\end{array}$ & $\begin{array}{c}\text { Data K- } \\
\text { Means }\end{array}$ \\
\hline 350705201 & Tidak Layak & $\begin{array}{c}\text { Sangat Tidak } \\
\text { Layak }\end{array}$ \\
000200900 & & Sangat Tidak \\
02002 & Layak \\
350705201 & Tidak Layak & Tidak Layak \\
000200900 & & \\
03003 & Tidak Layak & Tidak Layak \\
000200900 & & \\
04004 & & \\
350705201 & Tidak Layak & Tidak Layak \\
000200900 & & \\
05005 & Tidak Layak & \\
350705201 & & \\
000200900 & & \\
06006 & &
\end{tabular}

Berdasarkan tabel 6 dapat dilihat persentase untuk Correctly Clustering adalah sebesar 93\% sementara persentase untuk Incorrectly Clustering adalah sebesar 7\%. Dimana dari 106 data keluarga, ada sebanyak 99 data berhasil di clustering dengan benar dan sebanyak 7 data tidak berhasil di clustering dengan benar.

Berdasarkan Pengujian fungsional sistem Tabel 8 Pengujian Sistem dilakukan untuk menguji fitur-fitur yang ada pada sistem klasifikasi penentuan penerima bantuan pangan non tunai. Hasil pengujian sistem ditampilkan pada tabel 8 .

Tabel 8. Pengujian Fungsional

\begin{tabular}{|c|c|c|c|}
\hline NO & Modul Fungsi & $\begin{array}{c}\text { Berh } \\
\text { asil }\end{array}$ & Gagal \\
\hline 1 & $\begin{array}{l}\text { Login dengan } \\
\text { memasukkan no kartu } \\
\text { keluarga dan username } \\
\text { sesuai hak akses }\end{array}$ & $\sqrt{ }$ & $\mathrm{X}$ \\
\hline \multirow{6}{*}{2} & $\begin{array}{l}\text { Masuk ke system dengan } \\
\text { akses sebagai Admin }\end{array}$ & $\sqrt{ }$ & $\mathrm{X}$ \\
\hline & $\begin{array}{l}\text { a. Admin dapat melihat } \\
\text { data master }\end{array}$ & $\sqrt{ }$ & $X$ \\
\hline & $\begin{array}{l}\text { b. Admin dapat } \\
\text { menginputkan data } \\
\text { master }\end{array}$ & $\sqrt{ }$ & $\mathrm{X}$ \\
\hline & $\begin{array}{l}\text { c. Admin dapat } \\
\text { mengedit data master }\end{array}$ & $\sqrt{ }$ & $\mathrm{X}$ \\
\hline & $\begin{array}{l}\text { d. Admin dapat } \\
\text { menghapus data master }\end{array}$ & $\sqrt{ }$ & $\mathrm{X}$ \\
\hline & $\begin{array}{l}\text { e. Admin dapat } \\
\text { melakukan analisis data }\end{array}$ & $\sqrt{ }$ & $\mathrm{X}$ \\
\hline \multirow{5}{*}{3.} & $\begin{array}{l}\text { Masuk ke sistem sebagai } \\
\text { operator }\end{array}$ & $\sqrt{ }$ & $\mathrm{X}$ \\
\hline & $\begin{array}{l}\text { a. Operator dapat } \\
\text { menginputkan data } \\
\text { master }\end{array}$ & $\sqrt{ }$ & $\mathrm{X}$ \\
\hline & $\begin{array}{l}\text { b. Operator dapat } \\
\text { mengedit data master }\end{array}$ & $\sqrt{ }$ & $\mathrm{X}$ \\
\hline & $\begin{array}{l}\text { c. Operator dapat } \\
\text { mengedit data master }\end{array}$ & $\sqrt{ }$ & $\mathrm{X}$ \\
\hline & $\begin{array}{l}\text { d. Operator dapat } \\
\text { menghapus data master }\end{array}$ & $\sqrt{ }$ & $x$ \\
\hline
\end{tabular}

Pada tabel 8, pengujian fungsional menunjukkan hasil pengujian sistem yang telah dilakukan mendapatkan hasil bahwa sebagaian fungsi pada sistem telah berjalan dengan baik.

\section{KESIMPULAN DAN SARAN} 5.1. Kesimpulan

Berdasarkan pembahasan dan pengujian yang telah dilakukan maka didapat beberapa kesimpulan sebagai berikut : 
1. Berdasarkan hasil pengujian fungsional, Sistem Klasifikasi Penentuan Penerima BPNT sudah berjalan sesuai dengan apa yang telah diharapkan.

2. Hasil penelitian ini menunjukkan bahwa sistem penerima bantuan non tunai menggunakan metode K-Means Clustering menghasilkan data yang layak mendapatkan bantuan sesuai kriteria yang telah ditentukan.

\subsection{Saran}

Adapun saran-saran yang diperlukan untuk menindaklanjuti penelitian dan perbaikan untuk kedepannya adalah sebagai berikut :

1. Data yang digunakan dalam penelitian selanjutnya menggunakan data keluarga yang terbaru. Sehingga informasi yang dihasilkan juga informasi terbaru.

2. Pengembangan selanjutnya, perlu dicoba algoritma lainnya, missal algoritma K-NN untuk melakukan penentuan penerima bantuan pangan non tunai. sehinggga diharapkan penentuan yang dilakukan memiliki nilai akurasi yang lebih baik

\section{DAFTAR PUSTAKA}

[1] Yunita, F. (2018). Data Mining. Penerapan Data Mining Menggunakan Algoritma KMeans Clustering ( Stusi Kasus : Univeristas Islam Indragiri) .

[2] Prasetyo, E. (2014). Data Mining Mengolah Data Menjadi Informasi Menggunakan Matlab. Yogyakarta: ANDI Yogyakarta.

[3] Mahmudi, A., Nataly, S., Kusyanti, D, A. (2018). Penerapan Metode K-Means Clustering Pada Sistem Pendukung Keputusan Penentuan Status Gizi Batita.

[4] Sosial, K. (2019). Pedoman Umum Bantuan Pangan Non Tunai (BPNT). Jakarta: Tim Pengendali Pelaksanaan

Penyaluran Bantuan Pangan Secara Non Tunai.

[5] Komputer, W. (2010). Shortcourse SQ1 Server 2008 Express. Yogyakarta: Andi Yogyakarta. 